Journal of Mathematics and Statistics 8 (2): 191-194, 2012

ISSN 1549-3644

(C) 2012 Science Publications

\title{
Mathematics Teachers' Beliefs and Teaching Practices
}

\author{
${ }^{1}$ Effandi Zakaria and ${ }^{2}$ Siti Mistima Maat \\ ${ }^{1}$ Department of Educational Methodology and Practice, \\ Faculty of Education, Universiti Kebangsaan Malaysia, Bangi, Selangor \\ ${ }^{2}$ Mathematics Unit, Technical Foundation Section \\ Universiti Kuala Lumpur Malaysia France Institute, Bangi, Selangor
}

\begin{abstract}
Problem statement: The connection between teachers' beliefs and their practices were inconsistent among researchers. Previous experiences had become one of the factors involved in the fundamental process of teachers' learning and the beliefs system. Approach: This study was conducted to determine the mathematics secondary school teachers' beliefs and teaching practices. A total of 51 teachers from seven secondary schools were grouped according to their teaching experience and a set of questionnaires were given to them in order to get their responses on mathematics beliefs and their teaching practices. The dimensions of mathematics beliefs consist of beliefs towards the nature of mathematics, beliefs towards mathematics teaching and beliefs towards mathematics learning. Results: The result revealed no difference between the less-experienced and moreexperienced teachers in the aspects of mathematics beliefs. There was a moderate significant correlation between their mathematics beliefs and teaching practices. Conclusion: The establishment of good mathematical beliefs would lead teachers to positive and effective teaching practices.
\end{abstract}

Key words: Teachers' beliefs, teaching practices, learning mathematics, teaching mathematics, Mathematics Beliefs Questionnaire (MBQ)

\section{INTRODUCTION}

The research in mathematics beliefs is relevant with teachers' teaching practices (Watson and DeGeest, 2005). The research on beliefs focuses on the relationships among changes in beliefs and practices (Warfield et al., 2005). The teachers' abilities in creating meaningful classroom activities (Beswick, 2007) can be traced back to the three dimension of mathematics beliefs that include beliefs in the nature of mathematics, beliefs in teaching mathematics and beliefs in learning mathematics (Evans, 2003). Cooney and Lin (2001) commented that whatever the teachers did in the classroom was a product of their beliefs. The connection between teachers' beliefs and their practices are inconsistent among researchers (Beswick, 2007). The number of inconsistencies between these two variables has been examined by Beswick (2005) who reported a visible conflict. However, Kupari (2003) stated that teachers' beliefs are critical in the implementation of their teaching and learning process in classroom. Sikula et al. (1996) stated that life experience is a major contributor in shaping teachers' beliefs. Their teaching experience was a practical indicator about how teachers facilitated the changes that worked for their future development (Leder et al., 2003). Frykholm (1999) commented that previous experiences had become one of the factors involved in the fundamental process of teachers' learning and the beliefs system.

Stipek et al. (2001) reported that most researchers conducted the study on the connection of beliefs and practices are qualitative based. A review of this research has been done by Grouws (2006). Nevertheless, the result of a quantitative study that was carried out by Peterson et al. (1989) revealed a consistent relationship between teachers' beliefs and their practices. Swan (2006) stated that there existed discrepancies between mathematics beliefs and teaching practices. The issue on the importance of beliefs and practices in the development of mathematics education was raised by Ernest (1989).

Beswick (2005) stated that the connection between teachers' beliefs and their teaching practices in mathematics classroom was rather complex yet powerful. Raymond (1997) suggested a model to show the relationship between mathematics beliefs and teaching practices that would provide information on

Corresponding Author: Effandi Zakaria, Department of Educational Methodology and Practice, Faculty of Education, Universiti Kebangsaan Malaysia, Bangi, Selangor 
the understanding of the consistency of the variables. In addition, mathematics beliefs played an important role in filtering teachers' decisions during their instructional practice without relying on curriculum guidelines (Wittrock, 1986). How teachers used instructional strategies would give them an idea of what they could do when they became teachers. This process was continued when they were admitted to the teachers training program. During the process of learning to teach, the beliefs would be embedded in these preservice teachers and they would also be affected by the social factors in the educational institutions. Stipek et al. (2001) commented that teachers held their beliefs coherently, which in turn shaped their teaching practices. Much research has been done on the relationship between beliefs and teaching practices (Grouws, 2006); however, it is still relevant especially among the in-service teachers in Malaysia.

Research objectives: This study aims to investigate the mathematics beliefs and teaching practices of secondary school teachers. Specifically, the objective of the study was to determine:

- The mathematics beliefs of secondary school teachers according to their teaching experience

- The relationship between teachers' mathematics beliefs and their teaching practices based on their teaching experience

\section{MATERIALS AND METHODS}

Sample: Data for this study was gathered from 51 mathematics teachers from seven schools in Selangor, which are located in a rural area. Of the 51 teachers, 44 were females and 7 were males. These teachers were grouped according to the number of years of teaching experience. The respondents' profiles are shown in Table 1, which is based on their teaching experience. Most of them have more than ten years of teaching experience $(45.1 \%)$.

Instrumentation: Two instruments were used in this study; the Mathematics Beliefs Questionnaire (MBQ) and the Teachers Teaching Practices Questionnaire (TTPQ). Since the two instruments were adapted from a previous study, the researcher had to conduct back-toback translation. The original instruments were written in English; then, they were given to two experts in language for translation purposes. Descriptive statistics were used to identify the type of teaching practices used by the teachers involved in this study.
Table 1: Respondents' profile based on teaching experience

\begin{tabular}{llr}
\hline Teaching experience & Frequency & $\%$ \\
\hline $1-5$ years & 14 & 27.5 \\
$5-10$ years & 14 & 27.5 \\
More than 10 years & 23 & 45.1 \\
Total & 51 & 100.0 \\
\hline
\end{tabular}

Mathematics beliefs questionnaire: The mathematics beliefs questionnaire was adapted from Evans (2003) and has 36 items with three dimensions that include beliefs about the nature of mathematics, beliefs about mathematics teaching and beliefs about mathematics learning. A higher score indicates a belief consistent with a constructivist approach. The Cronbach alpha's value for MBQ was 0.77, which can be considered good (Hair and Anderson, 2010).

Teachers' teaching practices questionnaire: This instrument was adapted from Swan (2006) and Guffin (2008), which consisted of 25 items. A total of 13 items represent the teacher-centered teaching and 12 items belong to student-centered teaching. A 5 points likert scale was used. The Cronbach alpha's value for TTP was 0.60 , which was acceptable.

\section{RESULTS}

Teachers' mathematics beliefs: As shown in Table 2, teachers who had teaching experience between one and five years held better beliefs towards mathematics learning $($ mean $=4.09$, standard deviation $=0.46)$ as compared to the experienced teachers. The teachers' beliefs towards the nature of mathematics for those with more than ten years experience has the lowest mean value (mean $=3.37$, standard deviation $=0.32$ ) than the other group of teachers in the same dimension. The beliefs towards mathematics teaching showed the highest mean value for the less-experienced teachers $($ mean $=3.71$, standard deviation $=0.36)$.

A one-way Analysis of Variance (ANOVA) was used to determine the difference between the mean mathematics beliefs among these teachers based on their teaching experience. Table 3 shows that there was no significant mean difference for mathematics beliefs based on the teaching experience $(\mathrm{F}(2,48)=1.254, \mathrm{p}=0.295)$.

Teachers' mathematics beliefs and their teaching practices: The relationship between teachers' mathematics beliefs and their teaching practices:

As shown in Table 4, the relationship between teachers' mathematics beliefs and their teaching practices was found to be significant with moderate positive correlation $(\mathrm{r}=0.403, \mathrm{n}=51, \mathrm{p}=0.00)$. 


\section{J. Math. \& Stat., 8 (2): 191-194, 2012}

Table 2: Mean of mathematics beliefs according to teaching experience Mathematics beliefs dimension

Beliefs towards the Beliefs towards Beliefs towards

nature of mathematics mathematics teaching mathematics learning

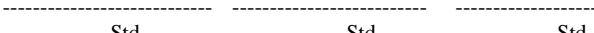

\begin{tabular}{lllllll}
$\begin{array}{l}\text { Teaching } \\
\text { experience }\end{array}$ & Mean & $\begin{array}{l}\text { Std } \\
\text { Deviation }\end{array}$ & Mean & $\begin{array}{l}\text { Std } \\
\text { Deviation }\end{array}$ & Mean & $\begin{array}{l}\text { Std } \\
\text { Deviation }\end{array}$ \\
\hline 1-5 years & 3.47 & 0.42 & 3.71 & 0.36 & 4.09 & 0.46 \\
5-10 years & 3.51 & 0.35 & 3.70 & 0.38 & 3.95 & 0.44 \\
More than & 3.37 & 0.32 & 3.59 & 0.32 & 3.95 & 0.34 \\
10years & & & & & & \\
\hline
\end{tabular}

Table 3: ANOVA of mathematics beliefs according to teachers' teaching experience

\begin{tabular}{llllll}
\hline $\begin{array}{l}\text { Mathematics } \\
\text { Beliefs }\end{array}$ & $\begin{array}{l}\text { Sum } \\
\text { of squares }\end{array}$ & Df & $\begin{array}{l}\text { Mean } \\
\text { square }\end{array}$ & F & Sig. \\
\hline Between groups & 0.19 & 2 & 0.09 & 1.25 & 0.295 \\
Within groups & 3.74 & 48 & 0.08878 & & \\
Total & 3.93 & 50 & & & \\
\hline
\end{tabular}

Table 4: Relationship between mathematics beliefs and teachers' mathematics beliefs

\begin{tabular}{lll}
\hline Variables & Mathematics beliefs & Sig \\
\hline Teaching Practices & $\mathrm{r}=0.403^{* *}$ & $\mathrm{p}=0.000$ \\
\hline ** Correlation is significant at the 0.01 level (2-tailed) &
\end{tabular}

\section{DISCUSSION}

In this study, the result revealed no difference between the less-experienced teachers and the moreexperienced teachers in the aspects of mathematics beliefs. The importance of experience for teachers is helpful as they can reevaluate their beliefs as their teaching experience increases (Stuart and Thurlow, 2000). The findings of this study also showed a positive connection between mathematics beliefs and the teachers' teaching practices. The result was consistent with the findings of a study that was conducted by Stipek et al. (2001). Ellerton (1999) stated that the teachers' beliefs in mathematics were derived from their experiences. The mathematics beliefs that they held has given impact to what they practiced when teaching. This is consistent with Wilson and Cooney (2002) assertion that teachers' beliefs were a crucial determinant in their classroom practice. Berliner and Calfee (1996) reported that mathematics beliefs had a significant influence on teachers' teaching practices.

\section{CONCLUSION}

The implication of teachers' beliefs on their teaching practices can be classified according to what they do in class. The teaching practices should reflect the kind of mathematics beliefs the teachers hold. According to Boz (2008), if the teachers wanted to promote the constructivist mathematical beliefs then, their class should portray the criteria of studentcentered teaching. Cohen and Ball (1990) suggested that reflection on teaching practices was considered to be an effective approach to alter teachers' beliefs. Teacher education should focus more attention on students' own thinking and reflection (Perkila, 2003). Accordingly, as teachers, we should dedicate all efforts to upgrading our teaching quality based on previous recommendations and research findings in order to increase the mathematical beliefs of teachers. The establishment of good mathematical beliefs would lead teachers to positive and effective teaching practices. It is suggested that future research should consider the effects of teacher education programs on teachers' mathematics beliefs and their teaching practices.

\section{REFERENCES}

Berliner, D.C. and R.C. Calfee, 1996. Handbook of Educational Psychology. 1st Edn., Macmillan Library Reference USA, New York, ISBN-10: 0028970896 pp: 1071.

Beswick, K., 2005. The beliefs/practice connection in broadly defined contexts. Math. Educ. Res. J., 17: 39-68.

Beswick, K., 2007. Teachers' beliefs that matter in secondary mathematics classrooms. Educ. Stud. Math., 65: 95-120. DOI: 10.1007/s10649-0069035-3

Boz, N., 2008. Turkish pre-service mathematics teachers' beliefs about mathematics teaching. Aus. J. Educ., 33: 66-80.

Cohen, D.K. and D.L. Ball, 1990. Policy and practice: An overview, Educ. Eval. Policy Anal., 12: 347-353. DOI: $10.3102 / 01623737012003233$

Cooney, T.J. and F.L. Lin, 2001. Making Sense of Mathematics Teacher Education. 1st Edn., Kluwer Academic Publ., Dordrecht, ISBN-10: 0792369858 pp: 335.

Ellerton, N.F., 1999. Mathematics Teacher Development: International Perspectives. 1st Edn., Meridian Press, West Perth, ISBN-10: 0958575401, pp: 256.

Ernest, P., 1989. Mathematics Teaching: The State of the Art. 1st Edn., Falmer Press, New York, ISBN10: 1850004609 pp: 279.

Evans, D.B., 2003. Early childhood (K-5) preservice teachers' beliefs about mathematics, teaching mathematics and learning mathematics. 1st Edn., Georgia Southern University, Thesis, pp: 291.

Frykholm, J.A., 1999. The impact of Reform: Challenges for mathematics teacher preparation. J. Math. Teacher Educ., 2: 79-105. DOI: 10.1023/A:1009904604728 
Grouws, D.A., 2006. Handbook of Research on Mathematics Teaching and Learning. 1st Edn., National Council of Teachers of Mathematics, Reston, ISBN-10: 9781593115982, pp: 784.

Guffin, B., 2008. Teacher beliefs towards inquirybased mathematical instruction strategies. South Dakota Elementary Schools, University of Dakota.

Hair, J.F. and R.E. Anderson, 2010. Multivariate Data Analysis. 7th Edn., Prentice Hall, Upper Saddle River, ISBN-10: 9780138132637 pp: 785.

Kupari, P., 2003. Instructional practices and teachers' beliefs in finnish mathematics education. Stud. Educ. Eval., 29: 243-257.

Leder, G.C., E. Pehkonen and G. Torner, 2003. Beliefs: A Hidden Variable in Mathematics Education? 1st Edn., Kluwer Academic Publishers, Dordrecht, ISBN-10: 1402010575 pp: 362.

Leder, G.C., E. Pehkonen and G. Torner, 2003. Beliefs: A Hidden Variable in Mathematics Education. 1st Edn., Kluwer Academic Publishers, Dordrecht, ISBN: 1402010575 pp: 362.

Perkila, P., 2003. Primary school teachers' mathematics beliefs and teaching practices. School of Halkokari, Kokkola.

Peterson, P.L., E. Fennema, T.P. Carpenter and M. Loef, 1989. Teachers'pedagogical content beliefs in mathematics. Cognition, Instruction, 6: 1-40.

Raymond, A.M., 1997. Inconsistency between a beginning elementary school teacher'smathematics beliefs and teaching practice. J. Res. Math. Educ., 28: 550-576. DOI: 10.2307/749691
Sikula, J.P., T.J. Buttery and E. Guyton, 1996. Handbook of Research on Teacher Education: A Project of the Association of Teacher Educators. 2nd Edn., Macmillan Library Reference, New York, ISBN-10: 0028971949, pp: 1190.

Stipek, D.J., K.B. Givvin, J.M. Salmon and V.L. MacGyvers, 2001. Teachers' beliefs and practices related to mathematics instruction. Teach. Teac. Educ., 17: 213-226.

Stuart, C. and D. Thurlow, 2000. Making it to their own: Preservice teachers' experiences, beliefs and classroom practices. J. Teacher Educ., 51: 113-124.

Swan, M., 2006. Designing and using research instruments to describe the beliefs and practices of mathematics teachers. Res. Educ., 75: 58-70.

Warfield, J., T. Wood and J.D. Lehman, 2005. Autonomy, beliefs and the learning of elementary mathematics teachers. Teach. Teach. Educ., 21: 439-456. DOI: 10.1016/j.tate.2005.01.011

Watson, A. and E. DeGeest, 2005. Principled teaching for deep progress: Improving mathematical learning beyond methods and materials. Educ. Stud. Math., 58: 209-234. DOI: 10.1007/s10649005-2756-X

Wittrock, M.C., 1986. Handbook of Research on Teaching. 3rd Edn., Collier Macmillan, New York, ISBN-10: 0029003105, pp: 1037. 